\title{
Association between land cover and Culicoides (Diptera: Ceratopogonidae) breeding sites on four Danish cattle farms
}

\author{
Carsten Kirkeby, René Bødker, Anders Stockmarr \& Claes Enøe
}

\begin{abstract}
Kirkeby, C., Bødker, R., Stockmarr, A. \& Enøe, C. 2009: Association between land cover and Culicoides (Diptera: Ceratopogonidae) breeding sites on four Danish cattle farms. - Entomol. Fennica 20: 228-232.

Biting midges of the genus Culicoides are vectors of bluetongue virus. Their larval habitats are poorly known in Northern Europe. Three classes of the CORINE land cover index, found within $300 \mathrm{~m}$ of four farms in Denmark, were used to stratify sampling sites for a total of 360 soil core samples from 30 sampling points. Soil samples were set up in emergence chambers for hatching adult Culicoides. Two species of Culicoides (C. punctatus and C. pulicaris) emerged from nine of 12 soil samples from a wet, grazed field with manure. Seventy-two other samples from similar land cover on the three other farms were negative. Seven sampling points from pastures were incorrectly classified by CORINE. The remaining 23 sampling points were classified correctly. The visually observed land use was not sufficiently detailed to adequately predict Culicoides breeding sites in this study. The CORINE index failed to identify pastures in which Culicoides breeding sites were found.
\end{abstract}

C. Kirkeby, R. Bødker, A. Stockmarr \& C. Enøe, National Reference Laboratory for Culicoides, National Veterinary Institute, Technical University of Denmark, Bülowsvej 27,DK-1790, Copenhagen V, Denmark; E-mails: ckir@vet.dtu.dk, rebo@vet.dtu.dk,anst@vet.dtu.dk, clen@vet.dtu.dk

Received 24 March 2009, accepted 9 October 2009

\section{Introduction}

Biting midges of the genus Culicoides are vectors of bluetongue virus that infects ruminants. The virus has caused a costly epidemic in large parts of North-West Europe since its introduction in 2006. Culicoides breeding ecology is poorly understood but important for virus research (Kettle 1977, Wilson \& Mellor 2008, Zimmer et al. 2008).

Larvae of Culicoides have a general preference for the top layer of permanently non-submerged humid environments (Blackwell \& King 1997, Uslu \& Dik 2006). Conte et al. (2007) stated that although up to $90 \%$ of Culicoides spp. breed in waterlogged habitats, the subgenus $A v a$ ritia (comprising the bluetongue vector C. obsoletus complex) favour drier, semi-moist habitats. Zimmer et al. (2008) found that larvae of the $C$. obsoletus complex were abundant in maize silage in Belgium, and Nielsen et al. (1998) demonstrated that members of the subgenus Culicoides (e.g. vectors $C$. punctatus and C. pulicaris) breed in a heavily polluted marsh area in Denmark. The public available digital CORINE index provides information about the land cover in Europe at a spatial resolution of $25 \mathrm{~m}$ based on remote sensing data from satellite images (EEA 2000). Thus, 


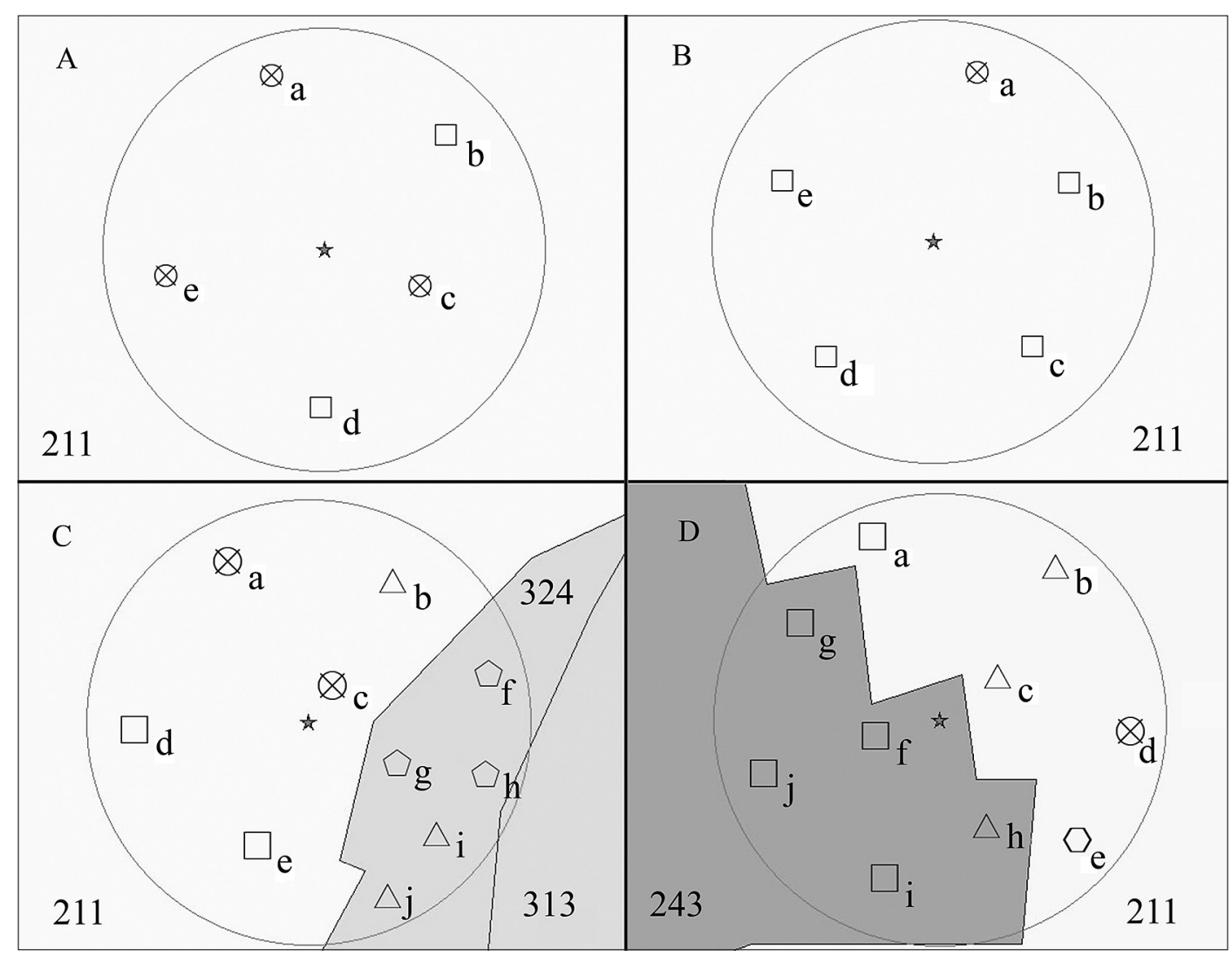

Fig. 1. The four locations with sampling points. In each sampling point, 12 soil samples were performed. Stars symbolize farms with light traps and the circles are their $300 \mathrm{~m}$ radius. Localities: A: Lille Skensved, B: Ølstykke, C: Randbøl, D: Fladen. Crossed circles = grazing; triangles = meadow; squares = crop fields (corn or grain); pentagons $=$ forest area; hexagon $=$ wetland. Numbers show the CORINE indices. The area with index 313 was omitted because of its small size. Culicoides spp. only hatched from sampling point $d$ on location D. Graphics: Carsten Kirkeby.

the CORINE index could be useful as a shortcut to predict Culicoides breeding sites near farms, as an alternative to visiting each farm and visually inspecting the surrounding areas, an expensive and time-consuming operation. The objective of this study was to evaluate if land cover classification, including the CORINE land cover index, around farms may be used to identify Culicoides breeding sites.

\section{Materials and methods}

Four locations (cattle farms) in Denmark were selected for this study. The CORINE 2000 index shows land cover classes based on satellite photos with the resolution of $25 \mathrm{~m}$. In Denmark, 31
CORINE classes are represented, of which four occurred within a $300 \mathrm{~m}$ radius of the four farms:

- Non-irrigated arable land (class 211)

- Land principally occupied by agriculture, with significant areas of natural vegetation (class 243)

- Transitional woodland/shrub (class 324)

- Mixed forest (class 313) (which was omitted due to its very small area within 300 m radius)

Before visiting each farm, five sampling points in each CORINE class within a $300 \mathrm{~m}$ radius were selected and plotted on the map, aiming at an evenly dispersed pattern, resulting in a total of 30 sampling points (Fig. 1). The $300 \mathrm{~m}$ distance was chosen on the basis of a study by Nielsen (1963) 
Table 1. Numbers of dominant Culicoides species caught in light traps four weeks after sampling. Soil samples were taken on the $29^{\text {th }}(\mathrm{B})$ and $31^{\text {st }}(\mathrm{A})$ of July and the $13^{\text {th }}(\mathrm{D})$ and $14^{\text {th }}(\mathrm{C})$ of August, corresponding to week 1 $(A, B)$ and $3(C, D)$.

\begin{tabular}{|c|c|c|c|c|c|}
\hline \multirow[b]{2}{*}{ Farm } & \multirow[b]{2}{*}{ Species } & \multicolumn{4}{|c|}{ Weeks after collection of soil samples } \\
\hline & & +1 & +2 & +3 & +4 \\
\hline \multirow[t]{3}{*}{$A$} & C. obsoletus complex & 992 & 74 & 31 & 44 \\
\hline & C. punctatus & 244 & 37 & 8 & 0 \\
\hline & C. pulicaris & 132 & 2 & 4 & 2 \\
\hline \multirow[t]{3}{*}{ B } & C. obsoletus complex & 102 & 18 & 26 & 157 \\
\hline & C. punctatus & 78 & 21 & 11 & 29 \\
\hline & C. pulicaris & 30 & 9 & 7 & 18 \\
\hline \multirow[t]{3}{*}{ C } & C. obsoletus complex & 130 & 221 & 192 & 218 \\
\hline & C. punctatus & 2 & 0 & 52 & 4 \\
\hline & C. pulicaris & 13 & 3 & 92 & 43 \\
\hline \multirow[t]{3}{*}{ D } & C. obsoletus complex & 197 & 181 & 0 & 9 \\
\hline & C. punctatus & 374 & 631 & 0 & 21 \\
\hline & C. pulicaris & 259 & 497 & 2 & 8 \\
\hline
\end{tabular}

where the majority of Culicoides were caught within $300 \mathrm{~m}$ of the breeding site, suggesting that the midges have a short flight range.

On each farm, the geographical coordinates from the map were located using GPS, and the present land use in the points was visually observed (Grazing; Meadow; Crop fields (corn or grain); Forest area; and Wetland). Twelve soil core samples were subsequently collected along the perimeter of a $2 \mathrm{~m}$ radius around each sample point with $50 \mathrm{~cm}$ distance between each sample. Samples were collected during a two week period in July and August 2008, just before the 2008 outbreak of bluetongue in northern Europe began (Conraths et al. 2009). The soil cores were exhumed using a metal pipe (97 $\mathrm{mm}$ in diameter) and were up to $7 \mathrm{~cm}$ deep, depending on the hardness of the soil. The resulting 360 soil samples were set up in emergence chambers modified from Dyce \& Marshall (1989), made of black painted plastic with a $13 \mathrm{~mm}$ funnel leading to a clear collection chamber. Emergence chambers were sealed with tape and kept in constant light at room temperature. For very dry samples (locations A and B) $5 \mathrm{ml}$ of tap water per centimeter soil depth were added to facilitate a humid environment for hatching. Emerging Culicoides were identified to the species level. A Poisson distribution was fitted to the sample points from which Culicoides emerged (positive sampling points), and a Goodness-of-Fit test was performed.
To compare the species ratios from the emergence traps with the adult Culicoides population, Culicoides were caught in Onderstepoort Blacklight traps on the same four cattle farms (location A, B, C, D), once a week for four weeks after soil sampling on each farm. Light trap samples were examined morphologically and the dominant Culicoides specimens identified to species or species complex level after Kremer (1965) and Niel$\operatorname{sen}(1982)$.

\section{Results}

In total, 35 Culicoides specimens hatched from the emergence chambers (34 C. punctatus and one $C$. pulicaris). All Culicoides emerged between day 19 and 61 from the sample date. Other insects hatched from the emergence traps from day 5 to day 200 when the samples were discarded. Culicoides emerged only from a single sampling point (Location $\mathrm{D}$, point $d$ ) occupied by grazing cattle. Six other sampling points on the three other farms were also occupied for grazing at the time of sampling, but none of these were positive. The only observed difference between the positive and the six other negative sampling points in grazing areas was wetter soil in the positive sampling point. All sampled grazed fields held a considerable amount of manure from the cattle. No Culicoides emerged from the 13 samp- 
le points collected from areas covered with crops; the three sampling points in areas with forest cover; the six sampling points in meadow areas; or from the single point in a wetland area.

In the positive sampling point, the 12 soil core samples yielded 14, 1, 0, 0, 4, 2, 3, 2, 0, 2, 5 and 2 adult Culicoides, respectively. The Goodness-ofFit test showed that the 12 different yields were not significantly different from a Poisson distribution $(p=0.46)$. Thus, the variation between samples may be due to random variation. Based on a Poisson approximation, the mean yield per soil sample was $2.91 \pm 0.97$ specimens. Each soil core sample covered $73 \mathrm{~cm}^{2}$ corresponding to a mean yield of $400 \pm 132$ adult Culicoides per $\mathrm{m}^{2}$ in the positive sampling point.

None of the seven sampling points from pastures were classified as Pastures (class 231) in CORINE, instead they were classified as Non-irrigated arable land (211) (Fig. 1). The remaining 23 sampling points were all classified correctly.

Culicoides were collected from light traps in all farms (Table 1). The three most dominant species on the farms were C. obsoletus (complex), C. punctatus and C. pulicaris.

\section{Discussion}

The soil sampling on the first two locations took place in a drier period than the last two, which is likely to have affected the amount of Culicoides eggs laid. However, numerous other insects hatched from all locations.

Breeding sites of the $C$. obsoletus complex, presumed to be the main vector of bluetongue in northern Europe are previously demonstrated to breed in bog land, marsh and, to a lesser extent, swamps and mud (Kettle \& Lawson 1952), middens, horse and cow dung (Campbell \& PelhamClinton 1960), moist forests and muddy soil (Trukhan 1975, Mirzaeva et al. 1976). Some of these habitats are not found within $300 \mathrm{~m}$ from the sampled farms which could explain why no specimens of this complex were hatched in this study. Although middens, horse and cow dung were found within the $300 \mathrm{~m}$ limit, they were not included in the random sampling. Muddy soil was sampled, but no specimens from the $C$. obsoletus complex hatched. Kettle \& Lawson (1952) found
$97 \%$ of $C$. obsoletus specimens in bog land and marsh whereas only 3\% were obtained from swamps and mud, which indicates that mud is not the preferred habitat of $C$. obsoletus.

The $C$. pulicaris complex breed in marsh, swamps and mud (Kettle \& Lawson 1952), and forest leaf-litter and ponds (Trukhan 1975, Mirzaeva et al. 1976). Kettle \& Lawson (1952) found $13-26 \%$ specimens of this complex in mud, which is the same type of habitat as where the specimens in this study also hatched.

The species composition on location D, was (C. pulicaris, C. punctatus, and C. obsoletus complex) 1:34:0 in the emergence traps and roughly $1: 2: 5$ in the light traps in the following four weeks, suggesting that important breeding sites of $C$. pulicaris and $C$. obsoletus were not sampled in the area or that these species were attracted to the light traps from outside the $300 \mathrm{~m}$ radius. The $C$. pulicaris : C. punctatus emergence ratio is very close to the results from Nielsen et al. (1998), who obtained 32 C. punctatus and $1 C$. pulicaris from 21 in situ emergence traps in a marsh polluted with organic material in Denmark during the summer of 1996. Thus, the positive sampling point in this study is quantitatively comparable with a eutrophic marsh area as a breeding site for $C$. punctatus and $C$. pulicaris.

Nielsen et al. (1998) found an emergence rate in the marsh area of up to 482.6 Culicoides per $\mathrm{m}^{2}$ in 23 weeks. In this study, the estimated density in the positive sampling point was $400 \pm 132$ Culicoides per $\mathrm{m}^{2}$. The two obtained densities are not directly comparable and further experiments are needed to estimate the ratio between in situ and in vivo hatching, and quantification of the efficiency of the emergence traps.

Since the Goodness-of Fit test on the samples in the positive sampling point showed no significant divergence between the Culicoides data and a standard Poisson distribution, the data showed no evidence of clustering of the number of adult Culicoides within this sampling point.

Only one of seven sample points in grazing cattle fields (from all four locations) was found positive, indicating that the visually observed land use is not accurate enough to predict Culicoides breeding sites. Thus, other more detailed measures must be used for prediction of Culicoides breeding sites. Since none of the seven 
sampling points from pastures were correctly classified by the CORINE index, it failed to predict the present land use. This problem could be due to crop rotation or that the CORINE index is too coarse for this purpose.

Based on this study, we recommend that other measures are included in the future prediction of Culicoides breeding sites. Methods such as LIDAR (light detection and ranging) or SAR (synthetic aperture radar) can detect e.g. soil moisture, topography, biomass, canopy height, leaf area and would thus be interesting to include in the further research (Wagner et al. 2009).

Acknowledgements. The authors would like to thank Henrik Skovgaard and Klaus Dahl at the Danish Pest Infestation Laboratory for providing light trap data, and Larry Paisley for comments on the manuscript.

\section{References}

Blackwell, A. \& King, F. C. 1997: The vertical distribution of Culicoides impunctatus larvae. - Medical and Veterinary Entomology 11: 45-48.

Campbell, J. A. \& Pelham-Clinton, E. C. 1960: A taxonomic review of the British species of "Culicoides" Latreille (Diptera, Ceratopogonidae). - Proceedings of the Royal Society of Edinburgh 67: 181-302.

Conraths, F. J., Gethmann, J. M., Staubach, C., Mettenleiter, T. C., Beer M. \& Hoffmann, B.: Epidemiology of Bluetongue Virus Serotype 8, Germany. — Emerging Infectious diseases 15: 433-435.

Conte, A., Goffredo, M., Ippoliti, C. \& Meiswinkel, R. 2007: Influence of biotic and abiotic factors on the distribution and abundance of Culicoides imicola and the Obsoletus Complex in Italy. - Veterinary Parasitology 150: 333-344.

Dyce, A. L. \& Marshall, B. D. 1989: An early record of Culicoides species (Diptera: Ceratopogonidae) developing in the dung of game animals in southern Africa. - The Onderstepoort Journal of Veterinary Research 56: 85-86.

EEA (European Environment Agency) 2000: CORINE land cover technical guide - Addendum 2000. Technical Report N 40. 225 pp.

Kettle, D. S. \& Lawson, J. W. H. 1952: The early stages of
British biting midges Culicoides Latreille (Diptera: Ceratopogonidae) and allied genera. - Bulletin of Entomological Research 43: 421-467.

Kettle, D. S. 1977: Biology and bionomics of bloodsucking ceratopogonids. - Annual Review of Entomology 22 : 33-51.

Kremer, M. 1965: Contribution à l'étude du genre Culicoides Latreille particulièrement en France - Faculté de Médecine de Strasbourg. Année 1961, No. 39: 1-299.

Mirzaeva, A. G., Glushchenko, N. P. \& Zolotarenko, G. S. 1976: Bio-geographical-ecological groupings of blood-sucking Ceratopogonids (Diptera, Ceratopogonidae) of Siberia. The fauna of helminths and arthropods of Siberia. - Fauna gel'mintov I chlenistonogikh Sibiri, Trudy Biologicheskogo Instituta, Sibirskoe Otdelenie, Akademiya Nauk SSSR. 18: $277-$ 290.

Nielsen, B. O. 1963: The biting midges of Lyngby Aamose (Culicoides: Ceratopogonidae). — Natura Jutlandica Naturhistorisk Museum, Aarhus. 10:1-46.

Nielsen, S. A. 1982: Systematiske og økologiske undersøgelser over mitter (Diptera: Ceratopogonidae: Culicoides Latr.) med særligt henblik på vektorproblematikken - Ph. D. Thesis, University of Aarhus.

Nielsen, S. A. Nielsen, B. O. Axelsen, J. Aa. \& Fotel, F. L. 1998: Forurening og formering af mitter i Egeløkke Lung. Larvetæthed og aktiviteter af voksne mitter. Miljøprojekt 423. - Miljø- og Energiministeriet, Miljøstyrelsen. 54 pp.

Trukhan, M. N. 1975: The effect of drainage improvement on the fauna and abundance of blood-sucking Ceratopogonidae. Problems of parasitology. — Proceedings of the VIIIth Scientific Conference of Parasitologists of the Ukrainian SSR. Volume 2.: Problemy Parazitologii. Materialy VIII Nauchnoi Konferentsii Parazitologov USSR. 2: 218-219.

Uslu, U. \& Dik, B. 2006: Vertical distribution of Culicoides larvae and pupae. - Medical and Veterinary Entomology 20: 350-352.

Wagner, W., Verhoest, N. E. C., Ludwig, R., \& Tedesco, M. 2009: Remote sensing in hydrological sciences. Hydrology and Earth System Sciences 13: 813-817.

Wilson, A. \& Mellor, P. 2008. Bluetongue in Europe: vectors, epidemiology and climate change. - Parasitology Research 103: 69-77.

Zimmer, J. Y., Haubruge, E., Francis, F., Bortels, J., Simonon, G., Losson, B., Mignon, B., Paternostre, J., De Deken, R., De Deken, G., Deblauwe, I., Fassotte, C., Cors, R. \& Defrance, T. 2008: Breeding sites of bluetongue vectors in northern Europe. - Veterinary Record 162:131. 